\title{
Spatial-temporal variations in surface ozone over Ushuaia and the Antarctic region: observations from in situ measurements, satellite data, and global models
}

\author{
Mohd Shahrul Mohd Nadzir ${ }^{1,2} \cdot$ Matthew J. Ashfold $^{3} \cdot$ Md Firoz Khan ${ }^{2}$. \\ Andrew D. Robinson ${ }^{4}$ - Conor Bolas ${ }^{4} \cdot$ Mohd Talib Latif $^{1,5} \cdot$ Benjamin M. Wallis $^{3}$ • \\ Mohammed Iqbal Mead ${ }^{6}$ Haris Hafizal Abdul Hamid ${ }^{1}$ - Neil R. P. Harris ${ }^{6}$. \\ Zamzam Tuah Ahmad Ramly ${ }^{7}$ - Goh Thian Lai ${ }^{1,3}$ • Ju Neng Liew ${ }^{1}$. \\ Fatimah Ahamad $^{1}$ - Royston Uning ${ }^{1}$ - Azizan Abu Samah ${ }^{8}$. \\ Khairul Nizam Maulud ${ }^{9,10}$ • Wayan Suparta ${ }^{11}$ - Siti Khalijah Zainudin ${ }^{11}$. \\ Muhammad Ikram Abdul Wahab ${ }^{12}$ - Mazrura Sahani ${ }^{12}$ Moritz Müller $^{13}$. \\ Foong Swee Yeok ${ }^{14}$ • Nasaruddin Abdul Rahman ${ }^{15}$ • Aazani Mujahid ${ }^{16}$. \\ Kenobi Isima Morris ${ }^{3,17}$ - Nicholas Dal Sasso ${ }^{18}$
}

Received: 25 April 2017 / Accepted: 18 October 2017 /Published online: 8 November 2017

(C) Springer-Verlag GmbH Germany 2017

\begin{abstract}
The Antarctic continent is known to be an unpopulated region due to its extreme weather and climate conditions. However, the air quality over this continent can be affected by long-lived anthropogenic pollutants from the mainland. The Argentinian region of Ushuaia is often the main source area of accumulated hazardous gases over
\end{abstract}

Responsible editor: Gerhard Lammel

Mohd Shahrul Mohd Nadzir

shahrulnadzir@ukm.edu.my

School of Environmental Science and Natural Resources, Faculty of Science and Technology, Universiti Kebangsaan Malaysia, 43600 UKM Bangi, Selangor, Malaysia

2 Centre for Tropical Climate Change System (IKLIM), Institute of Climate Change, Universiti Kebangsaan Malaysia, 43600 UKM Bangi, Selangor, Malaysia

3 School of Environmental and Geographical Science, University of Nottingham Malaysia Campus, Jalan Broga, 43500 Semenyih, Selangor, Malaysia

4 Centre of Atmospheric Sciences, Chemistry Department, University of Cambridge, Cambridge CB2 1EW, UK

5 Institute for Environment and Development (LESTARI), Universiti Kebangsaan Malaysia, 43600 Bangi, Selangor, Malaysia

6 Centre for Atmospheric Informatics and Emissions Technology, Cranfield University, Cranfield MK43 0AL, UK the Antarctic Peninsula. The main objective of this study is to report the first in situ observations yet known of surface ozone $\left(\mathrm{O}_{3}\right)$ over Ushuaia, the Drake Passage, and Coastal Antarctic Peninsula (CAP) on board the RV Australis during the Malaysian Antarctic Scientific Expedition Cruise 2016 (MASEC'16). Hourly $\mathrm{O}_{3}$ data was measured contin-

Department of Environmental Sciences, Faculty of Environmental Studies, Universiti Putra Malaysia, 43400 Serdang, Selangor, Malaysia

8 National Antarctic Research Centre, IPS Building, University Malaya, 50603 Kuala Lumpur, Malaysia

9 Earth Observation Centre (EOC), Institute of Climate Change, Universiti Kebangsaan Malaysia, 43600 Bangi, Selangor Darul Ehsan, Malaysia

10 Department of Civil and Structural Engineering, Faculty of Engineering and Built Environment,, Universiti Kebangsaan Malaysia, 43600 UKM Bangi, Selangor, Malaysia

11 Space Science Centre (ANGKASA), Institute of Climate Change Level 5, Research Complex Building, Universiti Kebangsaan Malaysia, 43600 UKM Bangi, Selangor, Malaysia

12 Environmental Health and Industrial Safety Program, School of Diagnostic Science and Applied Health, Faculty of Health Sciences, Universiti Kebangsaan Malaysia, Jalan Raja Muda Abdul Aziz, 50300 Kuala Lumpur, Malaysia 